\title{
Meningkatkan Kemampuan Motorik Kasar Melalui Parenting Senam Masal Ibu dan Anak Pada Anak Usia Dini TK Dharma Wanita Bangsal Kecamatan Pesantren Kota Kediri Tahun Pelajaran 2017/2018
}

\author{
S. Edy Subroto \\ TK Dharma Wanita Bangsal \\ Kota Kediri
}

\begin{abstract}
Abstrak
Penelitian ini dilatarbelakangi hasil pengamatan dan pengalaman peneliti, bahwa Berdasarkan pengamatan yang terjadi, rendahnya kemampuan motorik kasar anak tersebut dikarenakan belum maksimalnya pihak sekolah melaksanakan program pembelajaran yang melibatkan komponen wali murid. Permasalahan penelitian ini adalah Apakah dengan program parenting senam masal ibu dan anak dapat meningkatkan motorik kasar pada anak usia dini TK Dharma Wanita Bangsal Kecamatan Pesantren Kota Kediri Tahun Pelajaran 2017/2018. Penelitian Tindakan Kelas ini juga termasuk penelitian diskriptif karena menggambarkan bagaimana suatu pembelajaran diterapkan dan bagaimana hasil yang ingin dicapai. Penelitian Tindakan Sekolah dengan subyek penelitian ibu dan anak diTKDharma Wanita Bangsal Kecamatan Pesantren Kota Kediri ini dilaksanakan dalam 2 siklus. Dari hasil pelaksanaan siklus II yang sebesar $85,71 \%$ menunjukkan peningkatan motorik kasar anak usia dini sudah mencapai ketuntasan yang telah ditetapkan. Berdasarkan hasil penelitian tindakan sekolah yang dilakukan di TK Dharma Wanita Bangsal Kecamatan Pesantren Kota Kediri dapat disimpulkan bahwa melalui kegiatan parenting senam masal ibu dan anak dapat meningkatkan motorik kasar anak usia dini di TK Dharma Wanita Bangsal Kecamatan Pesantren Kota Kediri tahun pelajaran 2017/2018.
\end{abstract}

Kata kunci: Pendidikan motorik kasar, parenting, senam masal.

\section{PENDAHULUAN}

Pendidikan nasional berfungsi mengembangkan kemampuan dan membentuk watak serta peradaban bangsa yang bermartabat dalam rangka mencerdaskan kehidupan bangsa, bertujuan untuk berkembangnya potensi peserta didik agar menjadi manusia yang beriman dan bertakwa kepada Tuhan Yang Maha Esa, berakhlak mulia, sehat, berilmu, cakap, kreatif, mandiri, dan menjadi warga negara yang demokratis serta bertanggung jawab (pasal 3 UU Nomor 20 tahun 2003). Pada hakikatnya belajar harus berlangsung sepanjang hayat. Untuk menciptakan generasi yang berkualitas, pendidikan harus dilakukan sejak usia dini dalam hal ini melalui Pendidikan Anak Usia
Dini (PAUD), yaitu pendidikan yang ditujukan bagi anak sejak lahir hingga usia 6 tahun. Perkembangan fisik motorik khususnya keseimbangan tubuh anak juga termasuk usaha dalam mengoptimalkan pertumbuhan dan perkembangan tubuh anak melalui jenis-jenis aktivitas bermain yang mendukung.

Sementara itu, Husen dkk (2002) menyatakan bahwa "anak usia dini berada pada masa lima tahun pertama yang disebut The Golden Years, masa ini merupakan masa emas perkembangan anak". Anak pada usia tersebut mempunyai potensi demikian besar untuk mengoptimalkan segala aspek perkembangannya, termasuk perkembangan keterampilan motoriknya. Artinya 
perkembangan keterampilan motorik sebagai perkembangan unsur kematangan dan pengendalian gerak tubuh. Terdapat hubungan yang saling mempengaruhi antara kebugaran tubuh, keterampilan motorik dan kontrol motorik. Keterampilan motorik anak usia dini tidak akan berkembang tanpa adanya kematangan kontrol motorik, kontrol motorik tidak akan optimal tanpa kebugaran tubuh, kebugaran tubuh tidak akan tercapai tanpa latihan fisik.

Mengingat anak memiliki usia emas atau golden age. Usia emas anak ini harus diberikan stimulasi yang baik agar anak bisa berkembang dan tumbuh dengan segala potensi yang dimilikinya. Banyaknya manfaat pengembangan fisik atau motorik anak tentunya memerlukan arahan yang tepat dari para pendidik di TK selain dari orangtua anak-anak itu sendiri. Selain itu seorang pendidik (guru) di Taman Kanak-Kanak perlu merangsang minat anak untuk mau melakukan berbagai gerak dan ketrampilan olah fisik yang kelak dapat membantu anak-anak tersebut tumbuh menjadi pribadi yang cerdas, mandiri, dan sehat. Hal itu tentunya dapat dilakukan melalui penerapan berbagai strategi pembelajaran yang sesuai dengan usia perkembangan anak.

Pada umumnya anak mempunyai kecenderungan selalu ingin bergerak sambil bersenang-senang untuk menyalurkan segala potensi yang ada pada dirinya, sehingga dapat diwujudkan melalui berbagai bentuk permainan. Bermain bagi anak-anak TK merupakan suatu kebutuhan yang sangat penting di dalam kehidupannya, bahkan hampir sebagian dari waktunya dihabiskan untuk bermain. Pada masa ini terjadinya pematangan fungsi fisik dan psikis yang digunakan untuk mengembangkan seluruh potensi anak. Peningkatan ketrampilan motorik anak, berhubungan erat dengan kegiatan bermain yang merupakan aktivitas utama anak usia dini dengan aktivitas bermain positif, anak dapat menggunakan otot tubuhnya, menstimulasi penginderaannya, menjelajahi dunia sekitarnya dan mengenali lingkungan tempat tinggalnya, termasuk mengenali dirinya sendiri. Dengan demikian kemampuan motorik kasar anak akan semakin terlatih.

Perkembangan Anak Usia Dini merupakan salah satu komponen utama dalam memahami, menyusun dan mengembangkan program pembelajaran (bermain) pada satuan pendidikan anak usia dini. Pertumbuhan dan perkembangan yang diharapkan dicapai oleh anak pada rentang usia tertentu sangat mberpengaruh pada usia selanjutnya. Proses pertumbuhan anak yang mencakup pemantauan kondisi kesehatan, kemanan, perlindungan, dan gizi anak seharusnya mereka dapatkan sejak usia dini. Adapun proses perkembangan anak usia dini pada berbagai dimensi perkembangan dapat ditemu kenali melalui karakteristik tingkat pencapaian perkembangan pada rentang usia tertentu yang mengikuti pola-pola umum dalam perkembangan. Pola karakteristik umum perkembangan ini menjadi ukuran normative yang bersifat generik (umum) yang harus diadaptasi dengan melihat perkembangan aktual pada masing-masing anak. Berdasarkan pengamatan yang terjadi, dapat diketahui layanan pendidikan anak usia dini belum sepenuhnya dapat memberikan layanan yang maksimal, dimana program kesehatan belum ada, program gizi belum maksimal, program perlindungan anak juga belum ada. Rendahnya program holistik integratif tersebut dikarenakan belum maksimalnya pihak sekolah melaksanakan program parenting yang melibatkan komponen wali murid.

Peneliti melakukan pengamatan terhadap permasalahan yang terjadi di TK Dharma Wanita Bangsal Kecamatan Pesantren Kota Kediri menunjukkan bahwa upaya untuk meningkatkan kemampuan ketrampilan motorik kasar anak sudah dilakukan melalui berbagai permainan namun kebanyakan belum kreatif dan permainan kurang menstimulasi ketrampilan anak. Berdasarkan pengamatan peneliti, pengembangan kemampuan motorik kasar pada aspek senam mengikuti gerak musik sepenuhnya belum terwujud pada anak usia dini di TK Dharma Wanita Bangsal Kecamatan 
Pesantren Kota Kediri, dari 20 anak didik yang mendapatkan bintang $(\star \star \star \star) 4$ sebanyak 2 anak, bintang $3(\star \star \star)$ sebanyak 4 anak, dan bintang $(\star \star) 2$ sebanyak 9 anak serta yang mendapatkan bintang $(\star) 1$ sebanyak 5 anak, yang artinya hanya 6 anak atau 30\% sudah mampu senam dengan baik, sedangkan yang 14 anak atau $70 \%$ belum mampu senam dengan baik. Berdasarkan data di atas dapat diambil kesimpulan bahwa ketuntasan belajar dalam pengembangan kemampuamn motorik kasar melalui kegiatan senam belum tercapai.

\section{PERUMUSAN MASALAH}

Sesuai dengan latar belakang masalah diatas dan berdasarkan pengamatandi TK Dharma Wanita Bangsal Kecamatan Pesantren Kota Kediri Tahun Pelajaran 20172018 dapatdirumuskan masalah sebagai berikut:

Apakah dengan program parenting senam masal ibu dan anak dapat meningkatkanmotorik kasar anak usia dini di TK Dharma Wanita Bangsal Kecamatan Pesantren Kota Kediri Tahun Pelajaran 2017/2018?"

\section{KAJIAN PUSTAKA}

A. Pengertian Motorik Kasar Anak Usia Dini

Kemampuan manusia berkembang
sesuai kemampuan apa yang dikembangkannya, bagaimana seseorang tersebut menilai bahwa kemampuan yang akan dikembangkan adalah termasuk potensi dalam dirinya. Dalam kenyataanya, kemampuan apapun sangatlah penting untuk diasah mengingat satu kemampuan dengan kemampuan dalam diri saling beruhubungan. Stephen dalam Badeni (2013) telah mengklasifikasikan beberpa jenis kemampuan dalam diri seseorang yaitu:

1) Kemampuan Intelektual

Kemampuan intelektual
adalah kemampuan yang

diperlukan untuk melaksanakan aktivitas-aktivitas mental. Contoh tes IQ (Intelligent quotient) digunakan untuk menegaskan seberapa tingkat kemampuankemampuan intelektual umum. Ada 7 dimensi kemampuan intelektual, yaitu number aptitude, verbal comprehension, perceptual speed, inductive reasoning, spatial visualization memory.

2) Kemampuan Fisik

Kemampuan intelektual lebih besar memainkan peran pada pekerjaan-pekerjaan yang rumit yang menuntut berbagai persyaratan pemrosesan informasi sementara kemampuan fisik lebih banyak diperlukan pada aktivitas atau tugas-tugas yang menuntut stamina, kecekatan, kekuatan dan keterampilan atau bakat-bakat sejenis. Setiap orang memiliki kemampuan fisik dan tingkat stamina yang berbeda-beda.

Motorik kasar ini, berasal dari kata motorik dan kasar. Motorik itu sendiri merupakan sekumpulan kemamuan gerakan tubuh, baik gerakan kasar maupun gerakan halus. Kemampuan motorik selalu memerlukan koordinasi bagian-bagian tubuh sehingga latihan untuk aspek ini perlu diperhatikan (dalam Zainal, 2010).

\section{B. Pengertian Parenting}

Parenting adalah upaya pendidikan yang dilaksanakan oleh keluarga dengan memanfaatkan sumber-sumber yang tersedia dalam keluarga dan lingkungan yang berbentuk kegiatan belajar secara mandiri. Parenting sebagai proses interaksi berkelanjutan antara orang tua dan anak-anak mereka yang meliputi aktivitas-aktivitas sebagai berikut: memberi makan (nourishing), memberi petunjuk (guiding), dan melindungi (protecting) anak-anak ketika mereka tumbuh berkembang. Penggunaan kata "parenting" untuk aktivitas-aktivitas 
orang tua dan anak di sini karena memang sampai saat ini belum ada padanan kata dalam bahasa Indonesia yang tepat.

Keluarga sebagai unit sosial terkecil di masyarakat yang terbentuk atas dasar komitment untuk mewujudkan fungsi keluarga khususnya fungsi sosial dan fungsi pendidikan, harus benar-benar dioptimalkan sebagai mitra lembaga PAUD. Oleh karena itu melalui program parenting sebagai wadah komunikasi antar orang tua, disamping untuk memberikan sosialisasi terhadap program-program yang diselenggarakan oleh lembaga PAUD, secara umum tujuan program parenting, adalah mengajak para orang tua untuk bersama-sama memberikan yang terbaik buat anak-anak mereka. Sedangkan secara khusus tujuan pengembangan program parenting adalah:

Meningkatkan pengetahuan dan keterampilan orang tua dalam melaksanakan perawatan, pengasuhan dan pendidikan anak di dalam keluarga sendiri dengan landasan dasar-dasar kareakter yang baik.

C. Pengertian Senam

Senam adalah latihan tubuh yang dipilih dan diciptakan dengan berencana, disusun secara sistematis dengan tujuan membentuk dan mengembangkan pribadi secara harmonis (Margono, 2009:19). Senam dapat diartikan sebagai setiap bentuk latihan fisik yang disusun secara sistematis dengan melibatkan gerakangerakan yang terpilih dan terencana untuk mencapai tujuan tertentu (Sutrisno dan Khafadi, 2010:60).

Menurut Madijono (2010:1), senam adalah suatu bentuk latihan jasmani yang sistematis, teratur dan terencana dengan melakukan gerakangerakan yang spesifik untuk memperoleh manfaat dalam tubuh.
Sedangkan menurut Mahendra (2000:14), senam ialah kegiatan utama yang paling bermanfaat dalam mengembangkan komponen fisik dan kemampuan gerak (motorability).

Manfaat senam yaitu seseorang dapat memiliki bentuk tubuh yang ideal, diantaranya indah, bugar, dan kuat (Sutrisno dan Khafadi, 2010:145). Sedangkan menurut Agus Mahendra (2000:14), menyatakan manfaat senam meliputi manfaat fisik dan mental serta sosial.

Manfaat senam lainnya yaitu terjadi keseimbangan antara osteoblast dan osteoclast. Apabila senam terhenti maka pembentukan osteoblast berkurang sehingga pembentukan tulang berkurang dan dapat berakibat pada pengeroposan tulang. Senam yang diiringi dengan latihan stretching dapat memberi efek otot yang tetap kenyal karena di tengah-tengah serabut otot ada impuls saraf yang dinamakan muscle spindle, bila otot diulur (recking) maka muscle spindle akan bertahan atau mengatur sehingga terjadi tarik-menarik, akibatnya otot menjadi kenyal. Orang yang melakukan stretching akan menambah cairan sinoval sehingga persendian akan licin dan mencegah cedera (Suroto, 2004).

Apabila orang melakukan senam, peredaran darah akan lancar dan meningkatkan jumlah volume darah. Selain itu 20\% darah terdapat di otak, sehingga akan terjadi proses indorfin hingga terbentuk hormon norepinefrin yang dapat menimbulkan rasa gembira, rasa sakit hilang, adiksi (kecanduan gerak) dan menghilangkan depresi.

Selain itu, melalui senam akan memberikan sumbangan yang sangat besar dari program senam dalam meningkatkan self-concept (konsep diri). Ini biasa terjadi karena kegiatan senam menyediakan banyak pengalaman dimana akan mampu 
mengontrol tubuhnya dengan keyakinan dan tingkat keberhasilan yang tinggi, sehingga memungkinkan membantu membentuk konsep yang positif.

\section{METODE}

Penelitian ini merupakan penelitian tindakan dalam (action research) karena penelitian dilakukan untuk memecahkan masalah pembelajaran di kelas. Penelitian ini juga termasuk penelitian kualitatif yaitu metode penelitian berlandaskan pada filsafat postpositivisme, digunakan untuk meneliti kondisi obyek yang alamiah, (sebagai lawannya adalah eksperimen) dimana peneliti adalah sebagai instrumen kunci, pengambilan sampel sumber data dilakukan secara purposive dan snowball, teknik pengumpulan dengan trianggulasi (gabungan), analisis data bersifat induktif/kualitatif, dan hasil penelitian kualitatif lebih menekankan makna dari generalisasi (Sugiyono, 2013)

Sesuai dengan jenis penelitian yang dipilih yaitu penelitian tindakan, maka penelitian ini menggunakan model penelitian tindakan dari Kemmis dan Taggart (dalam Arikunto, 2002), yaitu berbentuk spiral dari siklus yang satu ke siklus yang berikutnya. Setiap siklus menjadi planning (rencana), action (tindakan), observation (pengamatan) dan reflction (refleksi). Langkah pada siklus berikutnya adalah rancangan yang sudah direvisi, tindakan, pengamatan dan refleksi. Sebelum masuk pada siklus I dilakukan tindakan pendahuluan yang berupa identifikasi permasalahan.

\section{HASIL}

\section{A. Siklus I}

Dari data di atas menunjukkan bahwa siklus I kemampuan motorik kasar dalam kegiatan senam masalibu dan anak pada anak usia dini TK Dharma Wanita Bangsal Kecamatan Pesantren Kota Kediri masih rendah, hal ini ditunjukkan dengan nilai rata-rata anak yang mendapatkan bintang 1 sebanyak 4 anak atau 2\%, yang mendapatkan bintang 2 sebanyak 8 anak atau $40 \%$, dan yang mendapatkan bintang 3 sebanyak 5 anak atau 25\%, serta yang mendapatkan bintang 4 sebanyak 3 anak atau $15 \%$. Sehingga kemampuan motorik kasar anak kegiatan senam masalibu dan anak di TK Dharma Wanita Bangsal Kecamatan Pesantren Kota Kediri pada siklus I sebanyak 8 anak atau $40 \%$, sedangkan 12 anak atau $60 \%$ belum mampu melempar dengan baik. Maka hal-hal yang kurang maksimal dalam pembelajaran pada siklus I, akan diperbaiki pada siklus II.

\section{B. Siklus II}

Dari data di atas menunjukkan bahwa kemampuan motorik kasar dalam kegiatan senam masal ibu dan anak di TK Dharma Wanita Bangsal mulai meningkat, hal ini ditunjukkan dengan nilai rata-rata anak yang mendapatkan bintang 1 sebanyak 0 anak atau $0 \%$, yang mendapatkan bintang 2 sebanyak 3 anak atau $15 \%$, yang mendapatkan bintang 3 sebanyak 6 anak atau $30 \%$, dan yang mendapatkan bintang 4 sebanyak 11 anak atau 55\%. Sehingga kemampuan motorik kasar anak dengan kegiatan senam masal ibu dan anak pada siklus II sebanyak 17 anak atau $85 \%$, sedangkan 3 anak atau 15\% belum mampu senam dengan baik.

\section{PEMBAHASAN}

Sejak pengamatan Siklus I sampai siklus II terdapat penjelasan tentang perkembangan menuju ke arah positif yaitu perkembangan fisik motorik kasar khususnya pada kegiatan senam masal ibu dan anak meningkat. Berbagai manfaat bisa diperoleh melalui kegiatan ini, antara lain mengembangkan kemampuan anak untuk melatih kelenturan otot tangan, dan ketangkasan anak. Pada siklus I anak belum mengalami ketuntasan belajar

Dijelaskan bahwa kegiatan senam masal ibu dan anak memiliki bertujuan 
meningkatkan kemampuan motorik kasar anak, sehingga pertumbuhan otot-otot terutama otot tangan akan semakin kuat, anak akan lebih senang dengan kegiatan senam masal ibu dan anak dengan sendirinya dapat mengembangkan kemampuan motorik kasar anak. Perkembangan motorik kasar anak dengan kegiatan senam masal ibu dan anak lebih mudah memasukkan pembelajaran yang berprinsip pada belajar sambil bermain, atau bermain seraya belajar pada anak usia dini. Dari data yang diperoleh dari siklus II sebesar $85 \%$ atau 17 anak sudah memenuhi kriteria ketuntasan sedangkan $15 \%$ atau 3 anak belum memenuhi kriteria ketuntasan, karena masih mendapat bintang 2 . Mereka masih membutuhkan dampingan dari guru jika mengerjakan sesuatu.

Berdasarkan latar belakang dan rumusan masalah serta hasil penelitian, maka hipotesis yang berbunyi melalui kegiatan senam masal ibu dan anak dapat meningkatkan kemampuan motorik kasar anak anak usia dini di TK Dharma Wanita Bangsal Kecamatan Pesantren Kota Kediri Diterima.

\section{SIMPULAN DAN SARAN}

\section{A. Simpulan}

Berdasarkan hasil penelitian yang dilakukan, diketahui bahwa terdapat peningkatan prosentase ketuntasan belajar anak mulai dari siklus I sebesar $40 \%$, meningkat $20 \%$, serta mencapai ketuntasan pada siklus II sebesar $85 \%$. Dengan demikian hipotesis dalam penelitian yang berbunyi pembelajaran melalui parenting kegiatan senam masal ibu dan anak dapat meningkatkan kemampuan motorik kasar anak usia dini di TK Dharma Wanita Bangsal Kecamatan Pesantren Kota Kediri, ini membuktikan bahwa hipotesis diterima.

\section{B. Saran}

Dengan memperhatikan penelitian tindakan kelas ini bahwa meningkatnya perkembangan motorik kasar anak melalui kegiatan senam masal ibu dan anak, maka peneliti menyampaikan beberapa saran sebagai berikut:

\section{Bagi Peneliti Selanjutnya}

Hasil penelitian kegiatan senam masal ibu dan anak di TK Dharma Wanita Bangsal Kecamatan Pesantren Kota Kediri dapat meningkatkan kemampuan motorik kaasar untuk itu, penelitian ini dapat dijadikan acuan atau referensi bagi pengembangan

penelitian selanjutnya.

2. Para Orangtua

Bagi para orangtua, sebaiknya juga ikut membantu dalam usaha peningkatan kemampuan motorik kasar anak, terutama saat anak berada dirumah. Anak sering dilatih dengan berbagai gerak yang ringan, seperti menyisir rambut sendiri, memakai baju sendiri, dan gerakan motorik kasar lainnya, sehingga kemampuan motorik kasar anak akan lebih berkembang dengan baik dengan tanpa membebankan gerakan yang melebihi usia dan perkembangan anak.

\section{DAFTAR RUJUKAN}

A. Marurti. 2008. Mengelola PAUD Dengan Aneka Permainan Meraih Kecerdasan Majemuk. Bantul: Kreasi Wacana.

Arikunto, Suharsimi. 1998. Prosedur Penelitian. Jakarta: Rineka Cipta.

Arikunto, Suharsimi.2002. Prosedur Penelitian Suatu Pendekatan Praktek. Bandung : Reneksa Cipta.
Aqib, Zainal. 2010. Pedoman Teknis Penyelenggaraan PAUD. Bandung: CV Nuansa Aulia. 
Badeni. 2013. Kepemimpinan dan Perilaku Organisasi.

Bandung:

ALFABETA.

CarolSeefeldt, Barbara A. Wasik. 2008. Pendidikan Anak Usia Dini. Menyiapkan Anak Usia Tiga, Empat, dan Lima Tahun Masuk Sekolah. Jakarta: PT Indeks.

Kunandar. 2008. Langkah Mudah Penelitian Tindakan Kelas Sebagai Pengembangan Profesi Guru. Jakarta: PT Raja Grafindo Perkasa.

Moesslicahtoen R. 1999. Metode Pengajaran di Taman KanakKanak. Malang : Departemen Pendidikan dan Kebudayaan.

Muawanah, Nurul. http.www.fungsiperkembangan-motorik-kasaranak-usia-dini. diakses pada tanggal 7 Januari 2011.

Munjin, Nasih, A. dkk. 2009. Metode dan Tehnik Pembelajaran Pendidikan Agama Islam. Bandung: PT Reflika Aditama.

Rachmawati Yeni dan Kurniati, Euis, 2010. Strategi Pengembangan Kreativitas Pada Anak. Jakarta: Kencana.

Rahyubi, Heri. 2012. Teori-teori Belajar dan Aplikasi Pembelajaran Motorik. Majalengka: Referens.

Sujiono, Bambang. dkk. 2007. Metode Pengembangan Fisik, Cet. 5, Jakarta: Universitas Terbuka.

Sujiono. Bambang, dkk. 2008. Metode Pengembangan Fisik. Jakarta: Universitas Terbuka.
Sujiono, Bambang, dkk. 2010. Metode pengembangan Fisik. Jakarta: Universitas Terbuka.

Suyadi. 2010. Psikologi Belajar Pendidikan Anak Usia Dini. Yogyakarta: PT Pustaka Insan Madani.

Sujiono, Yuliani Nurani. 2009. Konsep Dasar Pendidikan Anak Usia Dini. Jakarta: PT Indeks.

Sujiono, Yuliani Nurani. 2010. Bermain Kreatif Berbasis Kecerdasan Jamak. Jakarta: PT Indeks.

Subkhi, Akhmad. 2013. Pengantar Teori dan Organisasi. Jakarta: Prestasi Pustaka Raya.

Soetjiningsih. 2012. Tumbuh Kembang Anak. Jakarta: EGC.

Widarmi, D., Sriratna, G., dan Yulianti, 2008. Kurikulum Pendidikan Anak Usia Dini. Bandung: Falah Production.

Yusuf, S.L.N, 2009. Psikologi Perkembangan Anak dan Remaja. Bandung: Rosda. 